\title{
Pullulanase: Role in Starch Hydrolysis and Potential Industrial Applications
}

\author{
Siew Ling Hii,, ${ }^{1}$ Joo Shun Tan, ${ }^{2}$ Tau Chuan Ling, ${ }^{3}$ and Arbakariya Bin Ariff ${ }^{4}$ \\ ${ }^{1}$ Department of Chemical Engineering, Faculty of Engineering and Science, Universiti Tunku Abdul Rahman, \\ 53300 Kuala Lumpur, Malaysia \\ ${ }^{2}$ Institute of Bioscience, Universiti Putra Malaysia, 43400 Serdang, Selangor, Malaysia \\ ${ }^{3}$ Institute of Biological Sciences, Faculty of Science, University of Malaya, 50603 Kuala Lumpur, Malaysia \\ ${ }^{4}$ Department of Bioprocess Technology, Faculty of Biotechnology and Biomolecular Sciences, \\ Universiti Putra Malaysia, 43400 Serdang, Selangor, Malaysia
}

Correspondence should be addressed to Arbakariya Bin Ariff, arbarif@biotech.upm.edu.my

Received 26 March 2012; Revised 12 June 2012; Accepted 12 June 2012

Academic Editor: Joaquim Cabral

Copyright ( 2012 Siew Ling Hii et al. This is an open access article distributed under the Creative Commons Attribution License, which permits unrestricted use, distribution, and reproduction in any medium, provided the original work is properly cited.

\begin{abstract}
The use of pullulanase (EC 3.2.1.41) has recently been the subject of increased applications in starch-based industries especially those aimed for glucose production. Pullulanase, an important debranching enzyme, has been widely utilised to hydrolyse the $\alpha-1,6$ glucosidic linkages in starch, amylopectin, pullulan, and related oligosaccharides, which enables a complete and efficient conversion of the branched polysaccharides into small fermentable sugars during saccharification process. The industrial manufacturing of glucose involves two successive enzymatic steps: liquefaction, carried out after gelatinisation by the action of $\alpha$ amylase; saccharification, which results in further transformation of maltodextrins into glucose. During saccharification process, pullulanase has been used to increase the final glucose concentration with reduced amount of glucoamylase. Therefore, the reversion reaction that involves resynthesis of saccharides from glucose molecules is prevented. To date, five groups of pullulanase enzymes have been reported, that is, (i) pullulanase type I, (ii) amylopullulanase, (iii) neopullulanase, (iv) isopullulanase, and (v) pullulan hydrolase type III. The current paper extensively reviews each category of pullulanase, properties of pullulanase, merits of applying pullulanase during starch bioprocessing, current genetic engineering works related to pullulanase genes, and possible industrial applications of pullulanase.
\end{abstract}

\section{Introduction}

Starch is a major industrial raw material and is chemically and/or enzymatically processed into variety of products for subsequent use in various industries, ranging from food (especially high-fructose and glucose syrups) to washing detergent industries [1-3]. Starch is, after cellulose, one of the most abundant heterogeneous polysaccharide produced by plants in the form of water insoluble granules. It is a polymeric carbohydrate, composed of $\mathrm{C}, \mathrm{H}$, and $\mathrm{O}$ atoms in the ratio of $6: 10: 5,\left(\mathrm{C}_{6} \mathrm{H}_{10} \mathrm{O}_{5}\right)_{n}$. Molecules of starch are made of hundreds or thousands of glucose, corresponding to values of $n$ that range from 50 to several thousands. Glucose units are linked to one another through $C_{1}$ oxygen as glucosidic bond. Glucosidic bonds are stable under alkaline conditions while treatment of starch with acids or certain enzymes breaks the polymer into its constituent glucose molecules. The end unit of the polymeric chain has a latent aldehyde group and is known as the reducing end group.

Most starches are mixture of two polymers with high molecular weight: (i) a linear chain molecule-amylose, and (ii) a branch polymer of glucose-amylopectin. Starches of different origins have different amylose and amylopectin ratios which differ significantly in many physical properties $[4,5]$. In addition, the ratio of amylose to amylopectin in starch varies considerably depending on the origin, plant species, variety within plants, plants organs, age of organ, and growth conditions. This results in various crystalline organization of starch in the granules and henceforth different sensitivities of starch to enzymatic hydrolysis [6].

Amylose is the constituent of starch with anhydroglucose units linked by $\alpha-\mathrm{D}-1,4$ glucosidic bonds to form linear 


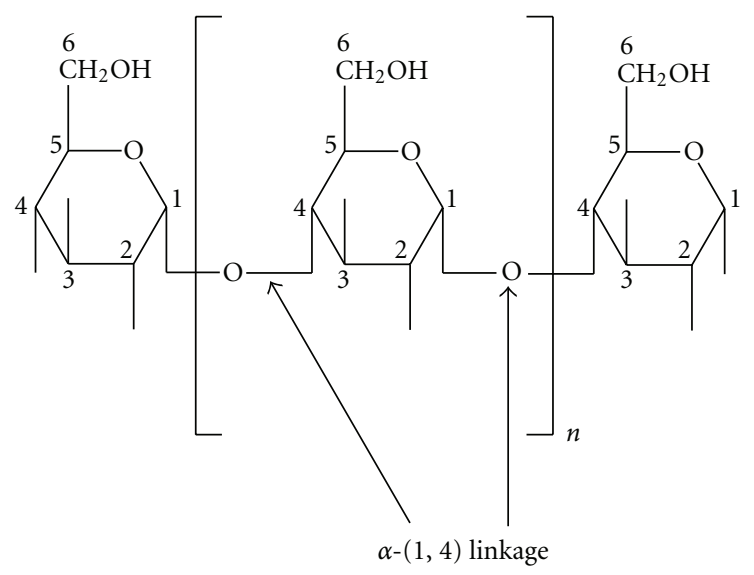

Figure 1: Section of the amylose molecule showing the repeating anhydroglucose unit (modified from [8]).

chains (Figure 1). A trace amount of branching is also present in the amylose molecule, although the side chains through branches are shorter in amylose than those in amylopectin [5]. The level of amylose and its molecular weight varies with types of starch. In addition, degree of polymerization (DP) of amylose covers a wide range, depending upon the starch source and origin. Aqueous solutions of amylose are very unstable due to intermolecular attraction and association of neighboring amylose molecules, which leads to increase in viscosity [7]. Retrogradation and precipitation of amylose particles may occur under certain specific conditions.

Amylopectin is one of the largest molecules in nature with an average DP of about 2 million. The molecular weight of amylopectin is about 1000 times as high as the molecular weight of amylose [8]. In addition to $\alpha$ D-1,4 bonds which are present in amylose and the linear segments of amylopectin, amylopectin molecule has $\alpha$-D1,6 bonds which occur every 20 to 30 anhydroglucose units (Figure 2). Glucose units with an $\alpha-1,6$ glucosidic linkages are the branching points which cause interlinkages of glucose residue that give rise to a ramified of bush-like structure of amylopectin molecule [9]. The branches in the amylopectin are not randomly organized but are clustered of $7 \mathrm{~nm}$ to $10 \mathrm{~nm}$ intervals (Figure 3), which are the universal features in structure of starch, regardless the source of botanical plant [10]. The branches themselves form an organized 3D structure: A-chains are not substituted at the $\mathrm{C}_{6}$ positions and inner B-chains are $\alpha$ - $(1,6)$-branches at one point or several points. The branching points make up about 5\% glucose unit in amylopectin [7]. Generally, most cereal starches possess A-chains pattern, while cereal starches rich in amylase, tuber such as potato and rhizome such as canna yield the B-chains pattern, where C-chains patterns are normally found in legume starches [10].

Aqueous solutions of amylopectin are characterised by high viscosity, clarity, stability, and resistance to gelling. Amylopectin binds weakly with iodine and the complex typically gives a red/brown color. The level of amylopectin varies with starch types. The majority of starches used in the manufacture of glucose syrups contain $75 \%$ to $85 \%$ of amylopectin [11] and in most plants, ranging from $60 \%$ up to $90 \%$, and reached about $100 \%$ in waxy cultivars of rice, maize, sorghum, barley, pea, and potato [5].

\section{Starch-Converting Enzymes}

The starch polymer, because of its complex structure, requires a combination of enzymes (endoamylases, and exoamylases) for the depolymerization of starch into oligosaccharides and smaller sugars, or to transform starch by transferring oligoglucosidic linkages and residues by the creation of new bonds (debranching enzymes and glycosyltransferases) $[3,12,13]$. The enzymes commonly used for starch processing are generically classified as amylases $[12,14]$. The process of enzymatic starch conversion is displayed in Figure 4. Basically, there are four types of starchconverting enzymes: (i) endoamylases; (ii) exoamylases; (iii) debranching enzymes; (iv) transferases.

2.1. Endoamylases. Endo-acting enzymes or endoamylases are able to cleave $\alpha-1,4$ glucosidic bonds present in the inner part (endo-) of the amylose or amylopectin chain. Enzyme $\alpha$-amylase (EC 3.2.1.1) is a well-known endoamylase that hydrolyses $\alpha-1,4$ linkages in the interior part of starch polymer in a random fashion, which leads to the formation of linear and branched oligosaccharides, or $\alpha$-limit dextrins. These enzymes are found in a wide variety of microorganisms, belonging to Bacteria and Archaea $[12,15]$.

2.2. Exoamylases. Exoamylases such as glucoamylases (EC 3.2.1.3) and $\alpha$-glucosidases (EC 3.2.1.20) cleave both $\alpha$-1,4 and $\alpha-1,6$ bonds on the external glucose residues of amylose or amylopectin from the nonreducing end and thus produce only glucose (glucoamylase and $\alpha$-glucosidases). On the other hand, $\beta$-amylases (EC 3.2.1.2) that cleave exclusively $\alpha-1,4$ bonds produce maltose and $\beta$-limit dextrin $[12,13,16$, 17].

2.3. Transferases. Transferases is another group of starchconverting enzymes that cleave an $\alpha-1,4$ glucosidic bond of the donor molecule and transfer part of the donor to a glucosidic acceptor with the formation of a new glucosidic bond. Enzymes such as amylomaltase (EC 2.4.1.25) and cyclodextrin glycosyltransferase (EC 2.4.1.19) form a new $\alpha$ 1,4 glucosidic bond while branching enzyme (EC 2.4.1.18) forms a new $\alpha-1,6$ glucosidic bond [3,12]. The third group of starch-converting enzymes is the debranching enzymes and is described in details in the following section.

\section{Starch-Debranching Enzymes}

Debranching enzymes catalyse the hydrolysis of $\alpha-1,6-$ glucosidic bonds in amylopectin and/or glycogen and related polymers. The affinity of debranching enzymes for the $\alpha$ 1,6-bond distinguishes these enzymes from other amylases which have primary affinity for $\alpha$-1,4-glucosidic linkages. Debranching enzymes are classified into two major groups, 


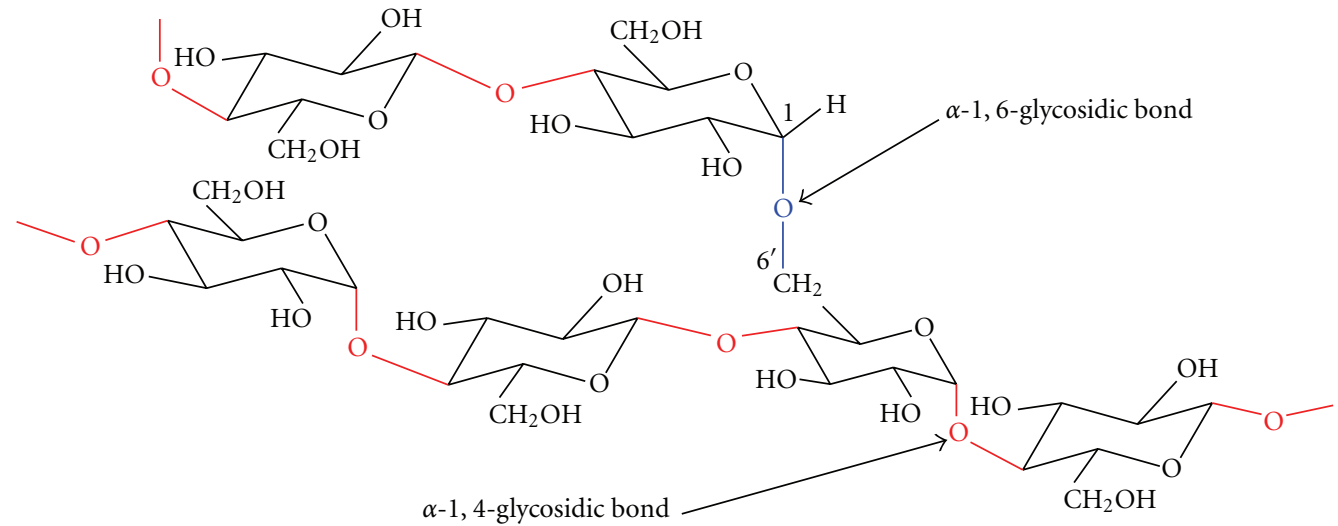

Figure 2: Section of the amylopectin molecule showing the $\alpha-1,4$ and $\alpha-1,6$ chain linkages in starch (modified from [8]).

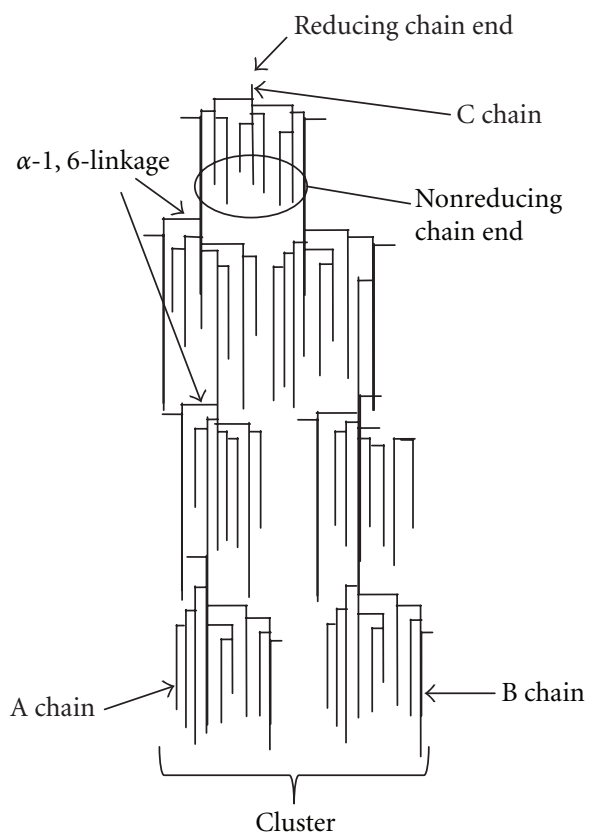

FIgURE 3: A diagram showing how the side-branching chains are clustered together within the amylopectin molecule (modified from [7]).

that is, direct and indirect [19]. As shown in Table 1, these enzymes may be divided into three major groups according to their substrate specificity: (a) microbial pullulanases and plant R-enzymes (pullulan-6-glucanohydrolases), (b) isoamylases (glycogen-6-glucanohydrolases), and (c) amylo1,6-glucosidases (dextrin 6- $\alpha$-D-glucosidases) found in higher microorganisms $[5,14,18,19]$.

3.1. Indirect Debranching Enzyme. The indirect debranching enzyme, that is, amylo-1,6-glucosidase, requires a modification of the substrate by another enzyme or enzymes prior to their debranching action $[18,19]$ and it is normally present in animal and yeast [5]. The amylo-1,6-glucosidase first requires the removal of an oligosaccharide by transglucosylase (4- $\alpha$-glucanotransferase, EC 2.4.1.25), leaving a glucose residue bound to a tetrasaccharide through a 1,6bond $[5,14,18]$. Amylo-1,6-glucosidase will only hydrolyse a 1,6- $\alpha$-branch point if the side chain consists of a single glucose unit. The smallest known substrate that amylo-1,6glucosidase can hydrolyze is the branched pentasaccharide $6^{3}$ - $\alpha$-glucosyl maltotetraose, which is hydrolyzed to glucose and maltotetraose (Figure 5). Amylo-1,6-glucosidases are not of industrial importance at present, so their properties and function are not described further in this paper.

3.2. Direct Debranching Enzymes-Pullulanase and Isoamylase. Direct-acting debranching enzymes which are present in plants and bacteria can directly hydrolyse $\alpha$-1, 6-glucosidic bonds of unmodified substrate and classified into pullulanases, isoamylases, or R-enzymes on the basis of substrate specificity.

Pullulanase. Pullulanase with EC 3.2.1.41 or also known as $\alpha$-dextrin 6-glucanohydrolase, pullulan 6-glucanohydrolase, limit dextrinase, and amylopectin 6-glucanohydrolase is derived from various microorganisms such as Bacillus acidopullulyticus, Klebsiella planticola [21], Bacillus deramificans [22], thermophilic Bacillus sp. AN-7 [23], Bacillus cereus FDTA-13 [24], and Geobacillus stearothermophilus [25]. Microbial pullulanase attracts more interest because of its specific action on $\alpha-1,6$ linkages in pullulan, a linear $\alpha$-glucan consisting essentially of maltotriosyl units connected by $1,6-$ $\alpha$-bonds. The structure of pullulan produced by the fungus, Aureobasidium pullulans, is shown in Figure 6.

To date, five groups of pullulan-hydrolyzing enzyme have been reported in the literature and the details are summarised in Table 2. Enzymes hydrolysing pullulan are classified into groups based on the substrate specificities and reaction products. Pullulanases type $\mathrm{I}$, which are able to hydrolyse efficiently the $\alpha$ - $(1,6)$ glucosidic bonds in pullulan and branched polysaccharides, have been extensively studied [26-30]. Pullulanases type II, also called amylopullulanases, are prominent in starch processing industry due to the specific debranching capacity of hydrolysing either $\alpha-(1,6)$ or $\alpha-(1,4)$ glucosidic linkages. This enzyme debranch pullulan and gives maltotriose as final product and it also attacks 


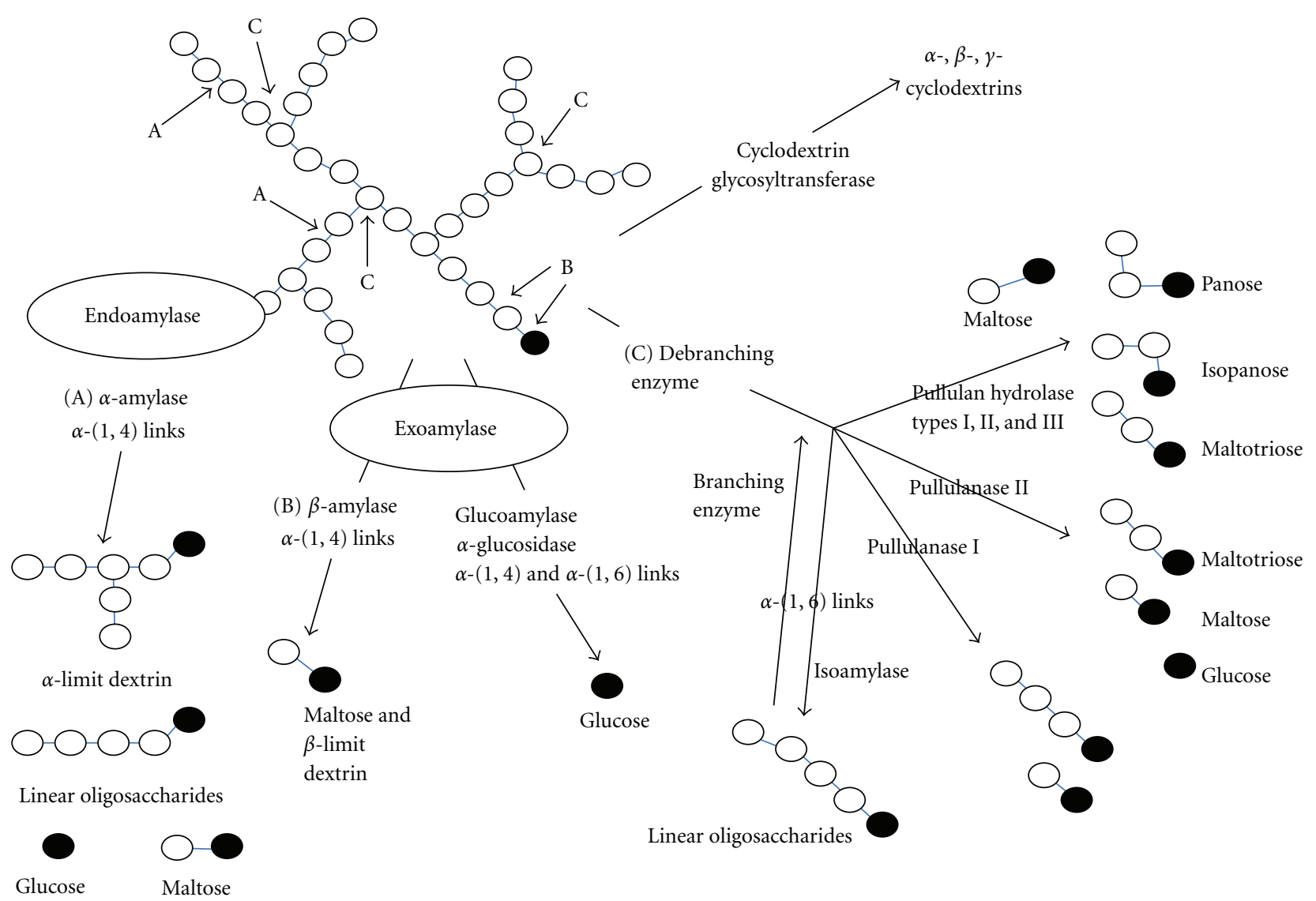

Figure 4: Schematic presentation of the action of amylases. Black circles indicate reducing sugars (modified from [17]).

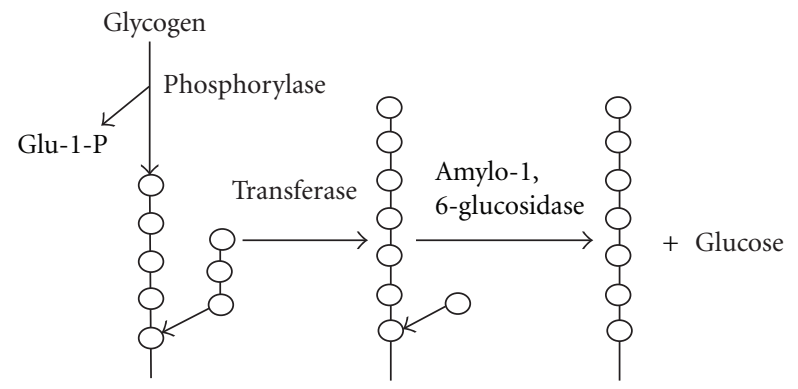

FIGURE 5: Action of amylo-1,6-glucosidase (modified from [18]).

$\alpha-(1,4)$ bonds in starch, amylose, and amylopectin $[3,12$, 31 . Both pullulanases type I and type II attach $\alpha-1,6$ glucosidic linkages in pullulan, producing maltotriose while these enzymes are unable to degrade cyclodextrin [32].

Very few reports are available on other pullulanases. Pullulan hydrolase type I (neopullulanase) and type II (isopullulanase) are only able to cleave $\alpha-1,4$ glucosidic linkages in pullulan, releasing panose and isopanose, and are highly active on cyclodextrins [32-34]. The enzymes that degrade cyclodextrins faster than starch are sometimes designated cyclodextrinases (EC 3.2.1.54, cyclomaltodextrinase) $[3,34]$. Interestingly, cyclomaltodextrinases are intracellular enzymes whereas most enzymes involved in starch conversion are extracellular [35]. These two types of pullulanhydrolysing enzyme (neopullulanase and isopullulanase) have practically no action on starch [36]. As these enzymes can precisely recognise the structural differences between $\alpha$ 1,4 and $\alpha-1,6$ glucosidic linkages, they are widely applied in structural analysis of oligo- and polysaccharides [31].

Unlike all pullulan-hydrolysing enzymes as described above, pullulan hydrolase type III detected by Niehaus et al. [37] has ability to attack $\alpha-(1,6)$ as well as $\alpha$ - $(1,4)$-glucosidic linkages in pullulan leading to the formation of a mixture of maltotriose, panose, maltose, and glucose. The enzyme is also able to degrade starch, amylose, and amylopectin forming maltotriose and maltose as main products.

Isoamylase. Isoamylase (EC 3.2.1.68) (glycogen 6-glucanohydrolase) is the only known enzyme that debranches glycogen completely. This enzyme contains two subunits with a molecular weight of 45000 , $\mathrm{pI}$ of $\mathrm{pH} 4.4$ and requires no metal cofactor. This enzyme is most active at $\mathrm{pH}$ ranging from $\mathrm{pH} 3$ to $\mathrm{pH} 4$ and has maximum temperature stability at $45^{\circ} \mathrm{C}$ to $55^{\circ} \mathrm{C}[1]$.

3.3. Comparisons between Pullulanase and Isoamylase. The major difference between pullulanase and isoamylase is that pullulanases hydrolyse the $\alpha-1,6$ glucosidic bond in pullulan 


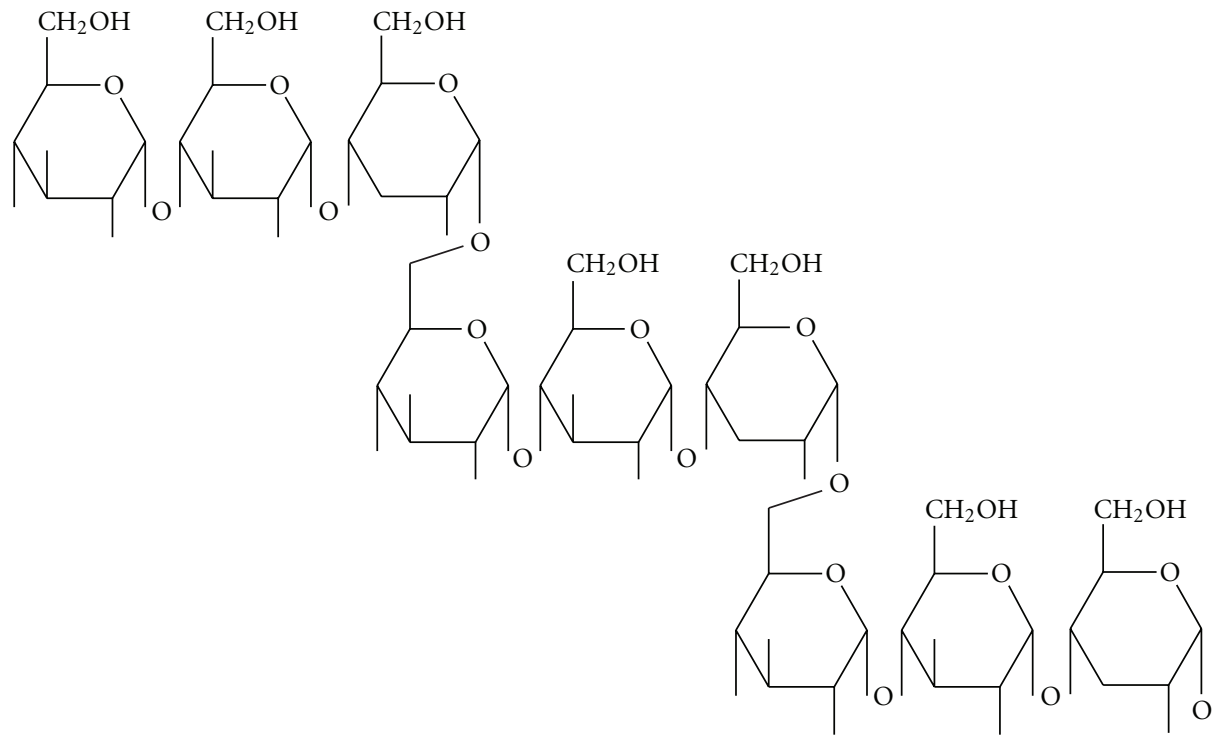

FIgURE 6: Generalized structure of pullulan from Aureobasidium pullulans strain CH-1 (modified from [2]).

TABLE 1: Carbohydrate structure requirements for hydrolysis of 1,6bonds by debranching enzymes. Symbols: $\downarrow$ : cleavage by enzyme mentioned; $\varnothing$ : reducing end.

\begin{tabular}{cc}
\hline Carbohydrate structure & Debranching enzyme involved \\
\hline & Amylo-1,6-glucosidase \\
\hline & \\
\hline
\end{tabular}

(Source: $[18,19])$.

and amylopectin, while isoamylase can only hydrolyse the $\alpha-1,6$ bond in amylopectin and glycogen [12]. Pullulanase requires each of the two chains linked by an $\alpha-1,6$ - glucosidic bond contains at least two $\alpha$-1,4-linked glucose units. Thus, the smallest substrate for pullulanase is the tetrasaccharide $6^{2}-\alpha$-maltosylmaltose. In contrast, isoamylase prefers substrates with high-molecular-weight oligosaccharides and the smallest substrate meeting this requirement is the pentasaccharide $6^{3}$ - $\alpha$-maltosyl maltotriose such as glycogen from animal sources [38]. The fine structure of amylopectin is distinct from that of glycogen in animals and bacteria as glycogen is randomly branched. The branches are more numerous, and the chains are shorter as compared to amylopectin [39].
The debranching enzyme from yeast and mold is known as isoamylase, and the enzymes produced by bacteria such as Aerobacter aerogenes or Klebsiella aerogenes are called pullulanase [14]. A comparison of the action of Klebsiella pneumoniae pullulanase and Pseudomonas amyloderamosa isoamylase on various substrates is given in Table 3. Although differing in their specificity, both types of enzymes directly hydrolyse $\alpha-1,6$ linkages in amylopectin, removing side branches of various lengths from the main polymer chain. The main chain and the side branches are then completely available for hydrolysis by other hydrolytic enzymes [10, 38].

During starch saccharification processes, formation of $\alpha$ limit and $\beta$-limit dextrins is the common phenomenon when amylopectin is treated with either $\alpha$-amylase or $\beta$-amylase, respectively. The concentrations of final glucose obtained in the saccharification are greatly reduced due to the present of these limit dextrins [38]. The bacterial pullulanases are able to hydrolyse amylopectin and its $\beta$-limit dextrins and attack the partially degraded polymer (Table 3 ). Therefore, pullulanases from either Klebsiella planticola or Bacillus acidopullulyticus are more commonly used than isoamylase (e.g., from Pseudomonas amylodermosa), mainly because of their greater temperature stability and more $\beta$-amylasecompatible $\mathrm{pH}$ range [10]. Another disadvantage of using isoamylase during saccharification process is the inability to hydrolyse 2- and 3-glucose unit side chains in $\beta$-limit and $\alpha$ limit dextrins. Thus, simultaneous action of $\beta$-amylase and isoamylase cannot quantitatively converts amylopectin to maltose [19]. The $\beta$-amylases are also found to be a potential inhibitor for the isoamylases activity [22]. Pullulanase, on the other hand, is generally used in combination with amyloglucosidase, $\alpha$-amylase, and $\beta$-amylase. Furthermore, the presence of maltotriose or maltotetraose in the fluid competitively inhibits isoamylase action [21].

The most established advantage of using pullulanase instead of isoamylase during starch saccharification process 
TABLE 2: Reaction specificities of pullulan-degrading enzymes.

\begin{tabular}{|c|c|c|c|c|c|}
\hline Enzyme & EC number & Bonds processed & Preferred substrate & End products & References \\
\hline Pullulanase type I & 3.2 .1 .41 & $\alpha-(1,6)$ & $\begin{array}{l}\text { Oligo- and } \\
\text { polysaccharides, Pullulan }\end{array}$ & Trimer (maltotriose) & {$[17,27]$} \\
\hline \multirow[b]{2}{*}{$\begin{array}{l}\text { Pullulanase type II } \\
\text { (amylopullulanase) }\end{array}$} & \multirow[b]{2}{*}{3.2 .1 .41} & $\alpha-(1,6)$ & Pullulan, & Trimer (maltotriose) & \multirow[b]{2}{*}{$\begin{array}{l}{[31,32,} \\
40]\end{array}$} \\
\hline & & $\alpha-(1,4)$ & $\begin{array}{l}\text { Poly- and oligosaccharide } \\
\text { (starch) }\end{array}$ & $\begin{array}{l}\text { Mixture of glucose, } \\
\text { maltose, and } \\
\text { maltotriose }\end{array}$ & \\
\hline $\begin{array}{l}\text { Pullulan hydrolase type I } \\
\text { (neopullulanase) }\end{array}$ & 3.2 .1 .135 & $\alpha-(1,4)$ & Pullulan & Panose & {$[41-43]$} \\
\hline $\begin{array}{l}\text { Pullulan hydrolase type II } \\
\text { (isopullulanase) }\end{array}$ & 3.2 .1 .57 & $\alpha-(1,4)$ & Pullulan & Isopanose & {$[12]$} \\
\hline \multirow[t]{2}{*}{ Pullulan hydrolase type III } & \multirow[t]{2}{*}{$3.2 .1 .-$} & \multirow[t]{2}{*}{$\begin{array}{c}\alpha-(1,4) \text { and } \\
\alpha-(1,6)\end{array}$} & Pullulan & $\begin{array}{l}\text { Mixture of panose, } \\
\text { maltose, and } \\
\text { maltotriose }\end{array}$ & \multirow[t]{2}{*}[37]{} \\
\hline & & & $\begin{array}{l}\text { Starch, amylose, and } \\
\text { amylopectin }\end{array}$ & $\begin{array}{l}\text { Maltotriose and } \\
\text { maltose }\end{array}$ & \\
\hline
\end{tabular}

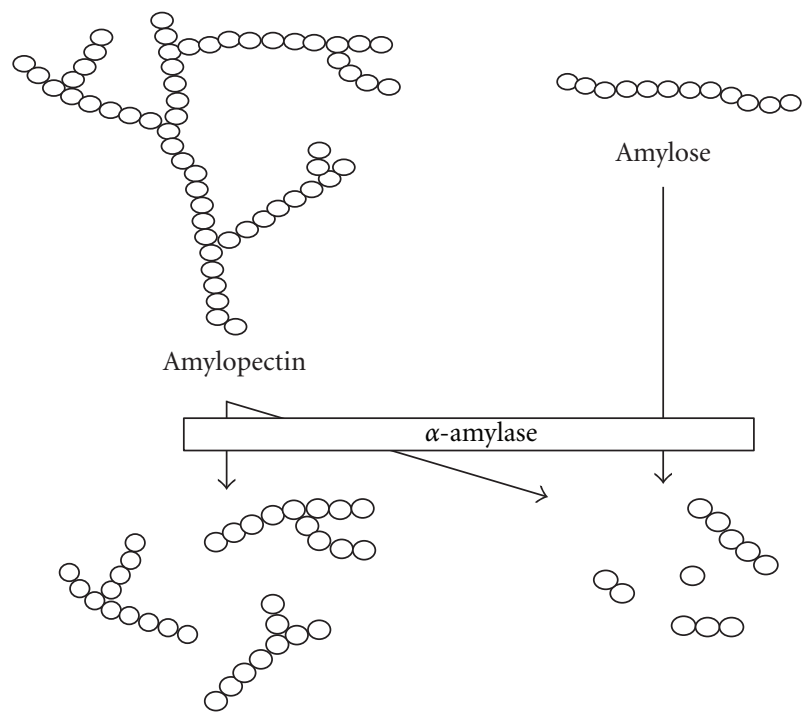

Figure 7: Partial hydrolysis of starch by $\alpha$-amylase (modified from [11]).

TABLE 3: Action of pullulanase and isoamylase on various substrates.

\begin{tabular}{lcc}
\hline Substrate & \multicolumn{2}{c}{ Relative rate of hydrolysis } \\
& Isoamylase & Pullulanase \\
\hline Pullulan & Very low & 100 \\
Pure amylopectin & 100 & 15 \\
Glycogen (oyster) & 124 & 1 \\
Rabbit liver & 111 & 0.6 \\
\hline
\end{tabular}

is that the time of addition of isoamylase to the hydrolysis system is very critical. For example, when isoamylase is used before amyloglucosidase, the amylopectin fraction is depolymerised too rapidly and therefore is highly susceptible to retrogradation [44].
3.4. Advantages of Using Pullulanase in Starch Saccharification Processes. The majority of starches which are of industrial importance contain approximately $80 \%$ amylopectin (Table 4). The branch points occur on average every 20 to $25 \mathrm{D}$-glucose units, so that amylopectin contains $4 \%$ to $5 \%$ of $\alpha-1,6$ glucosidic linkages [11]. During starch conversion process, starch is first gelatinised and solubilised at high temperatures and the long-chain molecules broken down into smaller units (maltodextrins) which can be either in the form of branch or linear (Figure 7).

The $\alpha$-1, 6-glucosidic linkages present in starch molecules act as a kind of barrier to the action of various starch hydrolysing enzymes during the saccharification process that followed after gelatinisation process. When starch is subjected to hydrolysis by $\alpha$-amylases, this endoacting enzyme is able to bypass the branch points, but in general is not capable of hydrolyzing the $\alpha-1,6$ glucosidic linkage. As a result, the amylopectin fraction is only partially degraded $[11,18]$. The branch points containing $\alpha-1,6$ glucosidic linkages are resistant to attack and their presence also imposes a certain degree of resistance on neighbouring $\alpha-1,4$ linkages. Thus, the prolonged action of $\alpha$-amylase on amylopectin results in the formation of " $\alpha$-limit dextrins," which are not susceptible to further hydrolysis by the $\alpha$-amylase (Figure 7). Similarly, when amylopectin is treated with $\beta$-amylase, hydrolysis stops as a $1,6-\alpha$ branch point is approached, resulting in the formation of $\beta$-limit dextrins [18].

During saccharification, partially hydrolysed amylose and amylopectin molecules are depolymerised by the action of glucoamylase which removes glucose units in a stepwise manner from the nonreducing chain ends [11, 45]. The rate of hydrolysis by glucoamylase depends on the particular linkage, size of molecule, and the order in which $\alpha-1,4$ and $\alpha$ 1,6 linkages are arranged [45]. Glucoamylase hydrolyses the $\alpha-1,4$ links very efficiently, and at a much slower rate for $\alpha$ 1,6 links. For example, the rates of hydrolysing $1,4-\alpha, 1,6-$ $\alpha$ and 1,3- $\alpha$-links in tetrasaccharides are in the proportion of $300: 6: 1[11,46]$. As shown in Figure 8, glucoamylases 

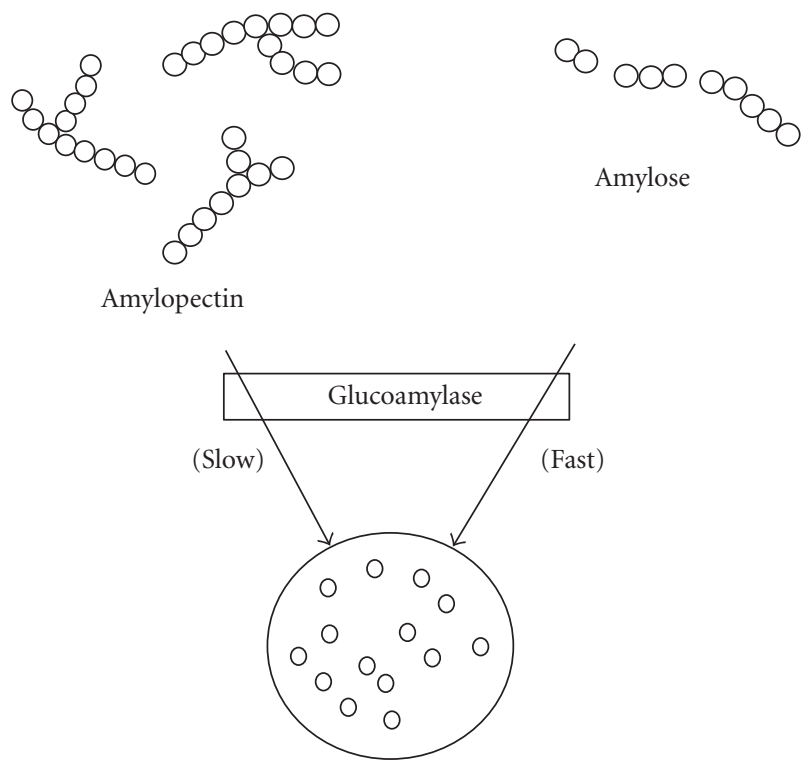

Glucose

FIgURE 8: Action of glucoamylase on liquefied starch (modified from [11]).

TABLE 4: Properties and composition of starch granules.

\begin{tabular}{lccccc}
\hline Starch & Type & Size range $($ diameter $\mu \mathrm{m})$ & Shape & Amylose $(\%)$ & Amylopectin $(\%)$ \\
\hline Sago & Pith & $5-65$ & Oval, truncated & 27 & 73 \\
Corn & Cereal & $3-26$ & Round, polygonal & 28 & 72 \\
Potato & Tuber & $5-100$ & Oval, spherical & 21 & 79 \\
Wheat & Cereal & $2-35$ & Round, reticular & 28 & 72 \\
Tapioca & Root & $4-35$ & Oval, truncated & 17 & 83 \\
Rice & Cereal & $3-8$ & Polygonal, angular & 17 & 83 \\
\hline
\end{tabular}

(Source: $[4,5]$ ).

slowly hydrolyse 1,6- $\alpha$-glucosidic linkages in amylopectin and partially hydrolyse amylopectin, but the action of this maltogenic exoamylases ceases or stops as a branch point is approached [11].

Glucoamylase also catalyses the reverse reaction (reversion), in which dextrose molecules are combined to form maltose and isomaltose [11, 38, 47]. When $\alpha$-amylase and glucoamylase are used in sequence to saccharify sago starch, the isomaltose is produced [48]. However, treatment with a mixture of glucoamylase and pullulanase during the saccharification of sago starch resulted in the production of glucose but no isomaltose. The reversion of dextrose specifically involves the condensation of a $\beta$-anomer of Dglucopyranose with either an $\alpha$ - or a $\beta$-D-glucose molecule in the presence of glucoamylase, as shown below:

$$
D \text {-glucose }+\beta \text { - } D \text {-glucose } \longrightarrow \text { Dissacharide }+\mathrm{H}_{2} \mathrm{O} \text {. }
$$

Isomaltose cannot be enzymatically hydrolysed into smaller molecule [22]. In industry, isomaltose is byproducts that decrease overall glucose yield and are unacceptable in the final high-fructose syrup used as sweetener [49]. Figure 9 shows the incubation of maltodextrin with high loading of glucoamylase which results in reduction of final glucose concentration due to continuous formation of isomaltose [12, 46]. Hence, minimising this reaction is important for increment of the final glucose yield in industrial process [45]. The efficiency of saccharification reaction could be improved by incorporating a specific amylopectindebranching enzyme in the system. If a debranching enzyme, such as pullulanase and glucoamylase, is simultaneously used during saccharification, the pullulanase would specifically hydrolyse the branch points in the amylopectin residues, followed by the hydrolysis of linear 1,4- $\alpha$-glucosidic linkages by glucoamylase (Figure 10). As a result, the maximum dextrose levels that could be achieved are higher (Figure 9) [20, 38].

The use of a debranching enzyme would increase the rate of overall saccharification process and reduce the total amount of glucoamylase that is required for complete conversion process. The practical advantage of using pullulanase together with glucoamylase is that less glucoamylase activity is needed. Reduction in the use of up to $60 \%$ glucoamylase has been reported $[11,50]$. This does not in itself give any cost advantage. However, less glucoamylase is used and fewer branched oligosaccharides accumulated toward the end of the saccharification and this is the point at which isomaltose production becomes significant [20]. 


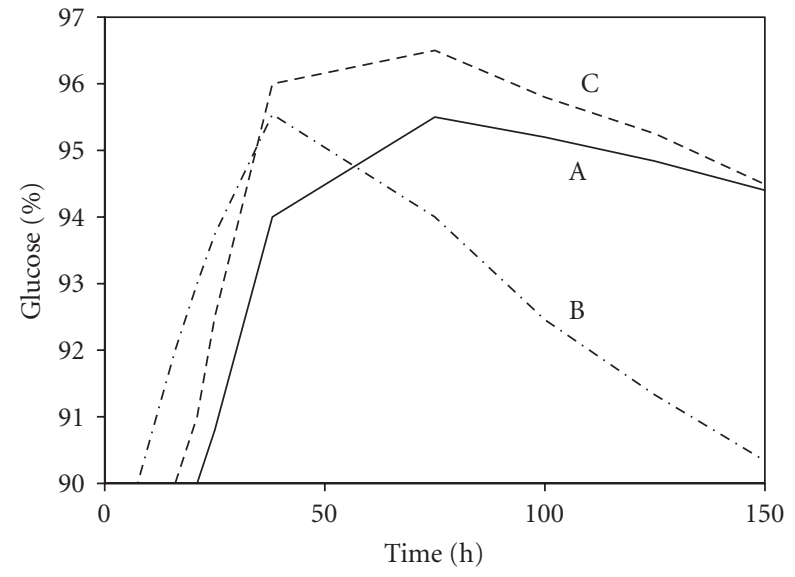

FIGURE 9: The percentage (\%) of glucose formed from maltodextrin using various enzyme solutions. Symbols: A, 200 U/kg Aspergillus niger glucoamylase; B, $400 \mathrm{U} / \mathrm{kg}$ Aspergillus niger glucoamylase; C, $200 \mathrm{U} / \mathrm{kg}$ Aspergillus niger glucoamylase plus $200 \mathrm{U} / \mathrm{kg}$ Bacillus acidopullulyticus pullulanase (modified from [20]).

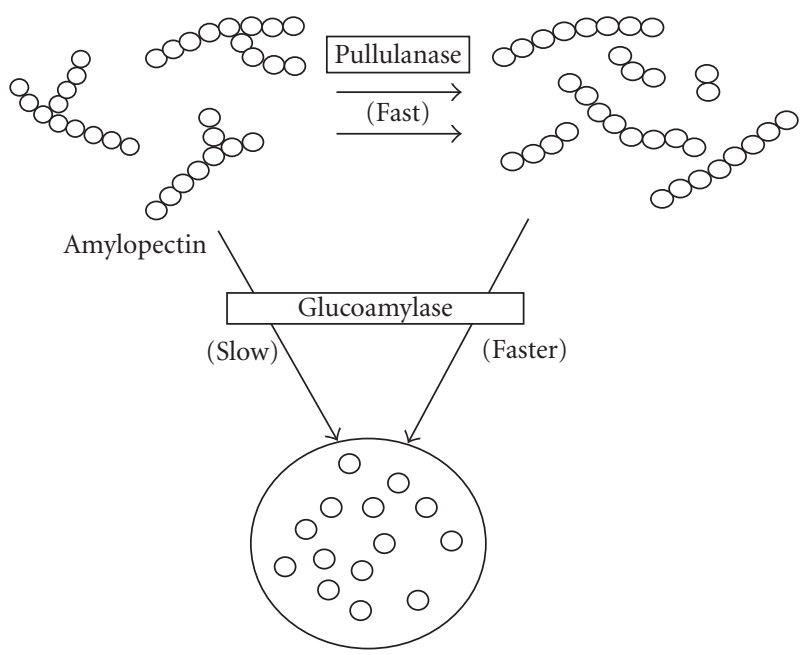

FIGURE 10: Effect of pullulanase during saccharification (modified from [11]).

The effect of pullulanase activity on the increment of Dglucose production is illustrated in Figure 11. In the standard saccharification process, without pullulanase, the maximum D-glucose that could be obtained under the given conditions is about $96 \%$. By using pullulanase, substantially lower glucoamylase dosage is possible to increase the D-glucose level by about $2 \%$. In addition, using pullulanase together with $\beta$-amylase in starch saccharification process, maltose yield could be increased by about 20 to $25 \%[11,50]$. By using pullulanase in the system, increase in crystallization yield could also be achieved for dextrose production. In order to obtain the targeted fructose concentration, pullulanase has been employed in fructose syrup production process, which in turn reduced the isomerization costs. For example, polysaccharide content in the final product can be reduced

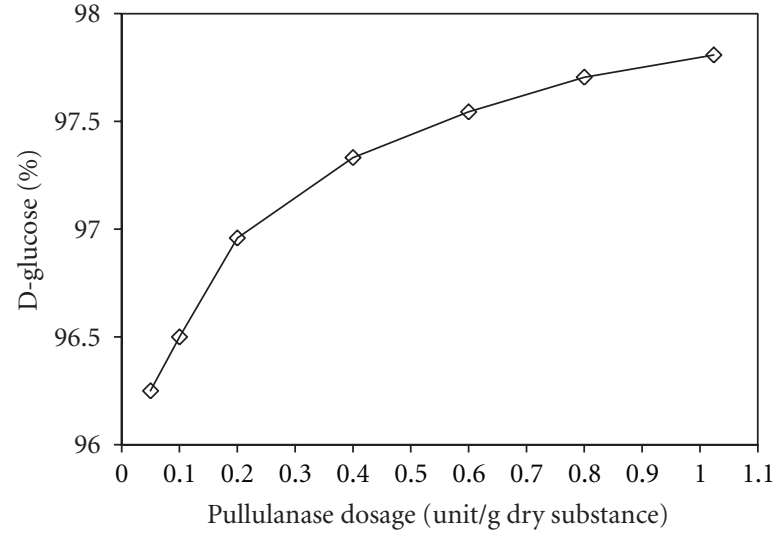

Figure 11: The effect of pullulanase activity on maximum Dglucose concentration (modified from [11]).

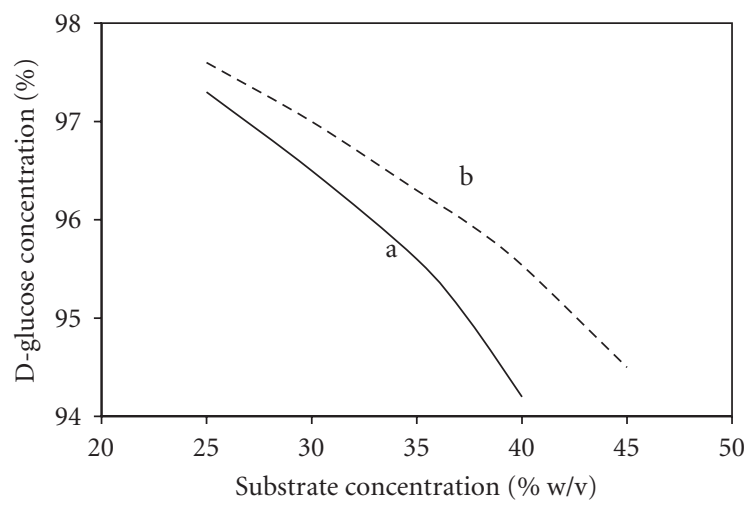

FIGURE 12: The effect of substrate concentration on maximum Dglucose concentration. Symbols: a, without pullulanase; b, with pullulanase (modified from $[11,18]$ ).

by up to about $50 \%$ in the production of $55 \%$ fructose syrup [11].

The effect of pullulanase on the amount of substrate that can be treated to produce maximum D-glucose is shown in Figure 12. Saccharification may be carried out at higher substrate concentrations ( $30 \%$ to $40 \%$ ) than in the normal process $(25 \%$ to $30 \%)$ if a combination of a debranching enzyme and glucoamylase is used $[20,50]$. Furthermore, the extra cost of using pullulanase is recouped by saving the cost of evaporation and glucoamylase. For high-fructose syrups production, cost of further processing could also be reduced [20].

The capacity of syrup production plant could be increased by reducing the starch saccharification time. In a conventional process, saccharification time could be increased by using high glucoamylase dosage and the time could be reduced from 45 to $30 \mathrm{~h}$ by doubling the dosage. Unfortunately, the reversion reaction (isomaltose formation from D-glucose) is very significant, and its therefore difficult to stop the saccharification at, or close to, maximum $\mathrm{D}$ glucose. If normal glucoamylase dosage with a combination of a debranching enzyme is used, the reaction time could be reduced without the problems of overconversion [11]. As 


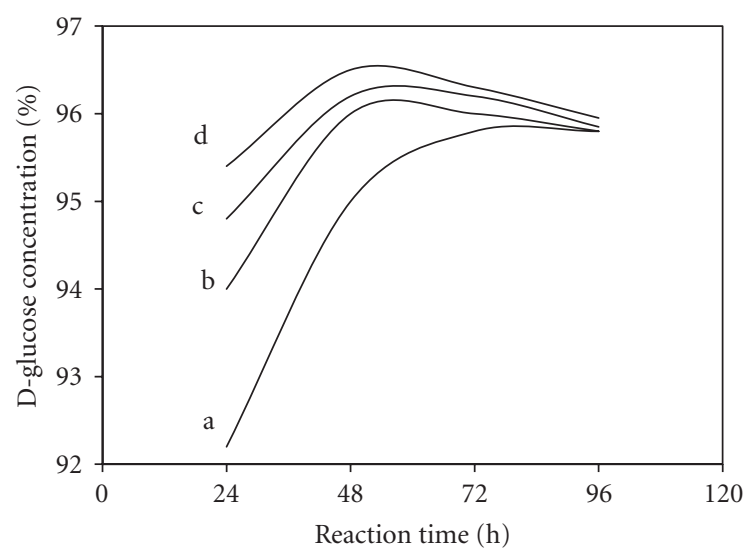

Figure 13: The effect of pullulanase dosage on reaction time. Symbols: a, without pullulanase addition; b, 0.04 unit of pullulanase/g dry solid; c, 0.08 unit of pullulanase/g dry solid; d, 0.16 unit of pullulanase/g dry solid (modified from [11]).

illustrated in Figure 13, for process without the debranching enzyme, maximum D-glucose was obtained after about $80 \mathrm{~h}$ of reaction. When the pullulanase loading is increased, the same level of $\mathrm{D}$-glucose can be attained at shorter incubation time $(30 \mathrm{~h})$.

3.5. Properties of Pullulanases. As mentioned earlier, enzymes which hydrolyse pullulan have been classified into five major groups. A number of pullulanases have been purified and characterised from different bacterial sources (Table 5). Pullulanase type I has been characterised from mesophilic bacteria such as Aerobacter aerogenes [69], Bacillus acidopullulyticus [11], Klebsiella pneumonia [70, 71], and Streptomyces sp. [52]. Moderate thermophilic grampositive bacteria such as Bacillus flavocaldarius [51], Bacillus thermoleovorans [30], Clostridium sp. [72], and Thermos caldophilus [27] also have ability to secrete pullulanase type I while pullulanase type I from hyperthermophilic bacterium, Fervidobacterium pennavorans, has also been reported [28].

Unlike pullulanase type I, pullulanase type II is widely distributed among extreme thermophilic Bacteria and hyperthermophilic Archaea [43]. The most thermostable and thermoactive pullulanase type II reported to date was derived from the hyperthermophilic archaeon Pyrococcus woesei [26] and Pyrococcus furiosus $[55,73]$. The temperature optima for these thermoactive pullulanase were ranged from $85^{\circ} \mathrm{C}$ to $105^{\circ} \mathrm{C}$ and maintained its thermostability even in the absent of substrate and calcium ions [17]. The gene encoding the pullulanase of Pyrococcus woesei was cloned and expressed in E. coli, which was the first archaeal pullulanase that was cloned and expressed in a mesophilic host [26]. With the present of $5 \mathrm{mM} \mathrm{Ca}^{2+}$, the activity of pullulanase type II produced by Pyrococcus furiosus and Thermococcus litoralis was active and stable at temperature ranging from $130^{\circ} \mathrm{C}$ to $140^{\circ} \mathrm{C}$ [55]. Thermoactive pullulanase type II from Desulfurococcus mucosus, Thermococcus celer, Thermococcus strain TYS, and Thermococcus strain TY has also been reported [56]. However, this hyperthermophilic pullulanase type II has not been yet in commercial production due to low yield and limited activity at high starch concentrations (>30\%) [74]. Several alkaline pullulanases type II, which were active at $\mathrm{pH}$ ranging from 8.5 to 12 , have been isolated and characterized from Bacillus spp. [41, 59, 75, 76].

Neopullulanases have been reported from many types of microorganisms such as Bacillus stearothermophilus [42], Bacteroides thetaiotaomicron 95-1 [57], and Bacillus polymyxa CECT 155 [58]. Neopullulanases hydrolyse pullulan to produce panose as the main product with the final molar ratio of panose, maltose, and glucose of $3: 1: 1$ [77]. Neopullulanase is also closely related to cyclomaltodextrinases based on similarity of their specific reaction towards pullulan [34]. Acidic isopullulanases have been characterised from Aspergillus niger ATCC 9642 [36] and Bacillus sp. US 149 [31]. Recently, pullulan hydrolase type III has been isolated and characterised from hyperthermophilic archaeon, Thermococcus aggregans [37]. This is the only enzyme presently known that attacks $\alpha-1,4$ - as well as $\alpha-1,6-$ glucosidic linkages in pullulan and is active at above $100^{\circ} \mathrm{C}$.

\section{Genetic Engineering of Pullulanase}

Wild-type microorganisms normally produce low activity of pullulanase enzymes, which are not enough to meet the demand for biotechnological applications. Molecular cloning of the corresponding genes and their expression in heterologous hosts is one of the possible approaches to circumvent this problem. Large quantities of specific gene can be isolated in pure form by molecular cloning and the target DNA can be produced in large amounts under the control of the expression vector. Overexpression following the cloning step can significantly increase the enzyme yield by subcloning the target gene into a suitable expression vector. Another approach is to insert a signal sequence into the host bacteria for the transfer of ligated gene product to the periplasmic region [78]. Research related to pullulanase gene has been carried out since 1980s. Most of the pullulanase genes were isolated from Bacillus spp. (Table 6). In addition, pullulanase genes from Anaerobranca gottschalkii, Desulfurococcus mucosus, and Klebsiella aerogenes have also been reported [24, 29, 60]; Escherichia coli and Bacillus subtilis were the two commonly used host strains for the expression of pullulanase gene.

\section{Industrial Applications of Pullulanase}

5.1. Saccharification of Starch. Since 1960s, almost all processes to convert starch to glucose have changed to enzymatic hydrolysis from traditional acid method [79]. Today, much of the starch hydrolysates available in the market are enzymeconverted products of higher DE. Dextrose equivalent (DE) is a measure of reducing sugar on a dry basis, pure dextrose (glucose) being DE 100 and starch being close to DE 0. The enzymatic conversion of starch into glucose, maltose, and fructose for use as food sweeteners represents an important growth area in industrial enzyme usage. The primary application of pullulanase is in starch saccharification and 
TABLE 5: Physicochemical properties of selected pullulan-hydrolyzing enzymes from various microorganisms.

\begin{tabular}{|c|c|c|c|c|c|}
\hline Organism & $M_{r}^{\mathrm{a}}(\mathrm{kDa})$ & $\mathrm{pI}$ & Optimal pH & Optimal temperature $\left({ }^{\circ} \mathrm{C}\right)$ & Reference \\
\hline \multicolumn{6}{|l|}{ Type I pullulanase } \\
\hline Bacillus flavocaldarius KP 1228 & 55 & n.d. ${ }^{\mathrm{b}}$ & 7.0 & $75-80$ & {$[51]$} \\
\hline Streptomyces sp. No. 27 & n.d. & n.d. & $4-7$ & $55-60$ & {$[52]$} \\
\hline Thermus caldophilus GK-24 & 65 & 6.1 & 5.5 & 75 & [27] \\
\hline Fervidobacterium pennavorans Ven 5 & 240 & n.d. & 6.0 & 85 & {$[28]$} \\
\hline Bacillus thermoleovorans US 105 (expressed in E. coli) & n.d. & n.d. & $5.6-6.0$ & 75 & {$[30]$} \\
\hline \multicolumn{6}{|l|}{ Type II pullulanase } \\
\hline Thermoanaerobacter strain B6A & 450 & 4.5 & 5.0 & 75 & {$[53]$} \\
\hline Clostridium thermosulfurigenes EM 1 & 102 & n.d. & $5.5-6.0$ & $60-65$ & {$[54]$} \\
\hline Pyrococcus furiosus & 110 & n.d. & 5.5 & 98 & {$[55]$} \\
\hline Thermococcus litoralis & 119 & n.d. & 5.5 & 98 & {$[55]$} \\
\hline Desulfurococcus mucosus & n.d. & n.d. & 5.0 & 100 & {$[56]$} \\
\hline Thermococcus celer & n.d. & n.d. & 5.5 & 90 & {$[56]$} \\
\hline Thermococcus strain TY & n.d. & n.d. & 6.5 & 100 & {$[56]$} \\
\hline Pyrococcus woesei & 90 & n.d. & 6.0 & 100 & {$[26]$} \\
\hline Thermococcus hydrothermalis & $110-128$ & n.d. & 5.5 & 95 & {$[14]$} \\
\hline Desulfurococcus mucosus expressed in Bacillus subtilis & 66 & n.d. & 5.0 & 85 & {$[32]$} \\
\hline \multicolumn{6}{|l|}{ Neopullulanases } \\
\hline Bacillus stearothermophilus expressed in B. subtilis & 62 & n.d. & 6.0 & $60-65$ & {$[42]$} \\
\hline Bacillus stearothermophilus TRS 40 & 62 & n.d. & 6.0 & $60-65$ & {$[42]$} \\
\hline Bacteroides thetaiotaomicron 95-1 & 70 & n.d. & 6.5 & 37 & {$[57]$} \\
\hline Bacillus polymyxa CECT 155 & n.d. & n.d. & 6.0 & 50 & {$[58]$} \\
\hline \multicolumn{6}{|l|}{ Isopullulanases } \\
\hline Aspergillus niger ATCC 9642 & $69-71$ & n.d. & 3.5 & 40 & {$[36]$} \\
\hline Bacillus sp. US 149 & 200 & n.d. & 5.0 & 60 & {$[31]$} \\
\hline \multicolumn{6}{|l|}{ Alkaline amylopullulanase } \\
\hline Bacillus sp. KSM-1876 & 120 & 5.2 & $10-10.5$ & 50 & [59] \\
\hline Bacillus sp. KSM 1378 & 210 & 4.8 & 9.5 & 50 & {$[41]$} \\
\hline \multicolumn{6}{|l|}{ Pullulan hydrolase type III } \\
\hline Thermococcus aggregans expressed in E. coli & n.d. & n.d. & 6.5 & 95 & [37] \\
\hline
\end{tabular}

${ }^{a}$ Molecular mass; ${ }^{b}$ not detected by the researchers.

TABLE 6: Genetic engineering of pullulanase gene.

\begin{tabular}{|c|c|c|c|c|}
\hline Source & Expression strain & Length $(a . a)^{*}$ & Vector & References \\
\hline Anaerobranca gottschalkii & E. coli BL21 (DE3) & 865 & pET21a & {$[60]$} \\
\hline Bacillus thermoleovorans US105 & E. coli $\mathrm{DH} 5 \alpha$ & 718 & pEBM2 & {$[30]$} \\
\hline Bacillus stearothermophilus TS-23 & E. coli XL1-Blue MRF & 2018 & $\mathrm{pAP} / \mathrm{StuI}$ & {$[61]$} \\
\hline Bacillus stearothermophilus strain TRS- 128 & B. subtilis NA-1 & N.A. ${ }^{\#}$ & pTB522 & {$[62]$} \\
\hline Klebsiella pneumonia & E. coli K-12 & N.A. ${ }^{\prime}$ & pACYC184 & {$[63]$} \\
\hline Thermus IM6501 & E. coli & 718 & p6xHis119 & {$[64]$} \\
\hline Desulfurococcus mucosus & B. subtilis clone JA803 & 686 & JA803 & {$[32]$} \\
\hline Fervidobacterium pennivorans Ven 5 & E. coli FD748 & 849 & pSE420 & {$[29]$} \\
\hline Thermococcus hydrothermalis & E. coli JM109 (DE) & 1339 & pAPU $\Delta 2$ & {$[65]$} \\
\hline Thermotoga maritima & E. coli JM83 & 840 & pTPU1 & {$[66]$} \\
\hline Caldicellulosiruptor saccharolyticus & E. coli Q359 & 826 & pNZ1038 & {$[67]$} \\
\hline Bacillus sp. XAL601 II & E. coli JM109 & 2032 & pUC18 & {$[68]$} \\
\hline
\end{tabular}

*a.a: amino acid.

${ }^{\#}$ N.A.: not available. 
the most important industrial application of pullulanase is in the production of high-glucose (30\% to $50 \%$ glucose; $30 \%$ to $40 \%$ maltose) or high-maltose (30\% to $50 \%$ maltose; $6 \%$ to $10 \%$ glucose) syrups $[12,80]$. In the saccharification process, pullulanase is normally used in combination with glucoamylase or $\beta$-amylase [13, 20,80].

5.2. Production of High-Maltose Corn Syrup. High-maltose syrups have mild sweetness, low viscosity in solution, low hygroscopicity, and good thermal stability. It is well suited for numerous applications in food processing such as in the manufacturing of high-quality candy and ice cream [81]. In recent years, there has been an increasing interest for pure maltose in the pharmaceutical industry. Maltose may be used instead of D-glucose for intravenous feeding, where it can be administered at higher concentrations without elevating blood glucose levels [81]. Pure maltose may also be used as a starting material for the production of maltitol and crystalline maltitol [11].

5.3. Production of High-Fructose Corn Syrup. High-glucose syrup is used as a carbon source in fermentation and feed for making high-fructose syrups and crystalline glucose [79, 82]. High-fructose syrup is produced by the treatment of high-dextrose syrup, especially high-glucose syrup (DE 9596) with immobilized glucose isomerase [12]. High-fructose corn syrup (HFCS) is a high-quality and clean-tasting caloric sweetener. HFCS with very high DE value is required in the production of crystalline glucose. HFCS is also widely used in product formulation. It is cheaper and less caloric than sucrose but 1.2 to 1.8 times sweeter than sucrose on a dry weight basis [44]. Like high-maltose syrup, 90\% HFCS is used in food for diabetics because it can be metabolized without insulin [83].

5.4. Starch Processing Industry. Pullulanase has also been used to prepare high-amylose starches, which have huge market demand [84]. High-amylose starches are of great interest and can be processed into "resistant starch" which has nutritional benefits [85]. Unlike normal starch, resistant starch is not digested in the small intestine but is fermented in the large intestine by gut bacteria, producing short-chain fatty acids such as butyrates that are beneficial for colon health. High-amylose starches are also used in adhesive products and in the production of corrugated board and paper [86].

5.5. Detergent. Some alkaline pullulanases have been used as effective additives in dishwashing and laundry detergents for the removal of starches under alkaline conditions $[76,87]$. The effectiveness of these alkaline debranching enzymes can be enhanced in washwater when the amylopullulanase is used in combination with alkaline $\alpha$-amylase because one single amylopullulanase can catalyze both debranching ( $\alpha$ 1,6 hydrolytic) and liquefying ( $\alpha-1,4$ hydrolytic) reactions [41].
5.6. Production of Cyclodextrins (CDs). Pullulanase has also been used to enhance the yield of cyclodextrins by the reaction of CGTase with gelatinized starches and maltodextrin syrups in the presence of cyclodextrins (CDs) complexing agents [88]. CDs have a wide range of applications in complexing materials in foods, pharmaceuticals, plastics, and agricultural products as emulsifiers, antioxidants, and stabilizing agents [89].

5.7. Others. Pullulanase also finds minor application in the manufacturing of low-calorie beer [79] and in baking industry as the antistaling agent to improve texture, volume, and flavor of bakery products [12]. It is also possible to use pullulanase as a dental plaque control agent [90].

\section{Conclusions}

Pullulanase capable of hydrolysing $\alpha-1,6$ linkages of polymer is widely used in saccharification process for production of various useful materials such as maltose, amylose, and glucose, by debranching starch with and without $\alpha$-amylase, $\beta$-amylase, or glucoamylase, respectively. Clearly, pullulanase could facilitate a major change in the current strategy for starch processing and hence, there is a strong demand for this enzyme around the world with a growing presence in the industries related to its usage.

\section{References}

[1] H. F. Zobel, "Starch: sources, production, and properties", in Starch Hydrolysis Products, F. W. Schenck and R. E. Hebeda, Eds., pp. 23-44, VCH, New York, NY, USA, 1992.

[2] L. Marchal, "Towards a Rational Design of Commercial Maltodextrines: a Mechanistic Approach,” 1999 http://www.bpe .wur.nl/UK/Research2/Dissertations/Enzymatic+starch+hydrolysis/Enzymatic+starch+hydrolysis+background/.

[3] C. F. V. Hobel, Access to biodiversity and new genes from thermophiles by special enrichment methods [Ph.D. thesis], University of Iceland, Iceland, 2004.

[4] J. J. M. Swinkels, "Sources of starch, its chemistry and physics," in Starch Conversion Technology, G. M. A. Vaan Beynum and J. A. Roels, Eds., pp. 115-145, Marcell Deckker, New York, NY, USA, 1985.

[5] Y. Nakamura, "Some properties of starch debranching enzymes and their possible role in amylopectin biosynthesis," Plant Science, vol. 121, no. 1, pp. 1-18, 1996.

[6] C. Martin and A. M. Smith, "Starch biosynthesis," Plant Cell, vol. 7, no. 7, pp. 971-985, 1995.

[7] R. F. Tester, J. Karkalas, and X. Qi, "Starch- composition, fine structure and architecture," Journal of Cereal Science, vol. 39, no. 2, pp. 151-165, 2004.

[8] M. S. Madihah, A. B. Ariff, K. M. Sahaid, A. A. Suraini, and M. I. A. Karim, "Direct fermentation of gelatinized sago starch to acetone-butanol-ethanol by Clostridium acetobutylicum," World Journal of Microbiology and Biotechnology, vol. 17, no. 6, pp. 567-576, 2001.

[9] S. Pérez and E. Bertoft, "The molecular structures of starch components and their contribution to the architecture of starch granules: a comprehensive review," Starch-Stärke, vol. 62, no. 8, pp. 389-420, 2010. 
[10] A. Reeve, "Starch hydrolysis: processes and equipment," in Starch Hydrolysis Product: Worldwide Technology, Production, and Applications, F. W. Schenck and R. E. Hebeda, Eds., pp. 79-120, VCH, New York, NY, USA, 1992.

[11] B. D. Jensen and B. E. Norman, "Bacillus acidopullyticus pullulanase: applications and regulatory aspects for use in food industry," Process Biochemistry, vol. 1, pp. 397-400, 1984.

[12] M. J. E. C. Van Der Maarel, B. Van Der Veen, J. C. M. Uitdehaag, H. Leemhuis, and L. Dijkhuizen, "Properties and applications of starch-converting enzymes of the $\alpha$-amylase family," Journal of Biotechnology, vol. 94, no. 2, pp. 137-155, 2002.

[13] G. D. Haki and S. K. Rakshit, "Developments in industrially important thermostable enzymes: a review," Bioresource Technology, vol. 89, no. 1, pp. 17-34, 2003.

[14] W. Gerhartz, Enzymes in Industry: Production and Applications, $\mathrm{VCH}, 1990$.

[15] A. Pandey, P. Nigam, C. R. Soccol, V. T. Soccol, D. Singh, and R. Mohan, "Advances in microbial amylases," Biotechnology and Applied Biochemistry, vol. 31, no. 2, pp. 135-152, 2000.

[16] R. N. Tharanathan and S. Mahadevamma, "Grain legumesa boon to human nutrition," Trends in Food Science and Technology, vol. 14, no. 12, pp. 507-518, 2003.

[17] C. Bertoldo and G. Antranikian, "Starch-hydrolyzing enzymes from thermophilic archaea and bacteria," Current Opinion in Chemical Biology, vol. 6, no. 2, pp. 151-160, 2002.

[18] B. E. Norman, "New developments in starch syrup technology," in Enzymes and Food Processing, pp. 15-51, 1981.

[19] W. M. Fogarty and C. T. Kelly, "Recent advances in microbial amylases," in Microbial Enzymes and Biotechnology, pp. 71132, Elsevier Applied Science Publishers, London, UK, 1990.

[20] M. Chaplin, "Production of syrups containing maltose," 2002, http://www.lsbu.ac.uk/biology/enztech/maltose.html.

[21] W. M. Teague and P. J. Brumm, "Commercial enzymes for starch hydrolysis products," in Starch Hydrolysis Products: Worldwide Technology, Production and Applications, F. W. Schenck and R. E. Hebeda, Eds., pp. 45-79, VCH, New York, NY, USA, 1992.

[22] H. Uhlig, Industrial Enzymes and Their Applications, WileyInterscience, New York, NY, USA, 1998.

[23] A. Kunamneni and S. Singh, "Improved high thermal stability of pullulanase from a newly isolated thermophilic Bacillus sp. AN-7," Enzyme and Microbial Technology, vol. 39, no. 7, pp. 1399-1404, 2006.

[24] S. U. Nair, R. S. Singhal, and M. Y. Kamat, "Induction of pullulanase production in Bacillus cereus FDTA-13," Bioresource Technology, vol. 98, no. 4, pp. 856-859, 2007.

[25] S. Zareian, K. Khajeh, B. Ranjbar, B. Dabirmanesh, M. Ghollasi, and N. Mollania, "Purification and characterization of a novel amylopullulanase that converts pullulan to glucose, maltose, and maltotriose and starch to glucose and maltose," Enzyme and Microbial Technology, vol. 46, no. 2, pp. 57-63, 2010.

[26] A. Rudiger, P. L. Jorgensen, and G. Antranikian, "Isolation and characterization of a heat-stable pullulanase from the hyperthermophilic archaeon Pyrococcus woesei after cloning and expression of its gene in Escherichia coli," Applied and Environmental Microbiology, vol. 61, no. 2, pp. 567-575, 1995.

[27] C. H. Kim, O. Nashiru, and J. H. Ko, "Purification and biochemical characterization of pullulanase type I from Thermus caldophilus GK-24," FEMS Microbiology Letters, vol. 138, no. 2-3, pp. 147-152, 1996.

[28] R. Koch, F. Canganella, H. Hippe, K. D. Jahnke, and G. Antranikian, "Purification and properties of a thermostable pullulanase from a newly isolated thermophilic anaerobic bacterium, Fervidobacterium pennavorans Ven5," Applied and Environmental Microbiology, vol. 63, no. 3, pp. 1088-1094, 1997.

[29] C. Bertoldo, F. Duffner, P. L. Jorgensen, and G. Antranikian, "Pullulanase type I from Fervidobacterium pennavorans Ven5: cloning, sequencing, and expression of the gene and biochemical characterization of the recombinant enzyme," Applied and Environmental Microbiology, vol. 65, no. 5, pp. 2084-2091, 1999.

[30] E. Ben Messaoud, Y. Ben Ammar, L. Mellouli, and S. Bejar, "Thermostable pullulanase type I from new isolated Bacillus thermoleovorans US105: cloning, sequencing and expression of the gene in E. coli," Enzyme and Microbial Technology, vol. 31, no. 6 , pp. 827-832, 2002.

[31] A. Roy, E. B. Messaoud, and S. Bejar, "Isolation and purification of an acidic pullulanase type II from newly isolated Bacillus sp. US149," Enzyme and Microbial Technology, vol. 33, no. 5, pp. 720-724, 2003.

[32] F. Duffner, C. Bertoldo, J. T. Andersen, K. Wagner, and G. Antranikian, "A new thermoactive pullulanase from Desulfurococcus mucosus: cloning, sequencing, purification, and characterization of the recombinant enzyme after expression in Bacillus subtilis," Journal of Bacteriology, vol. 182, no. 22, pp. 6331-6338, 2000.

[33] F. Niehaus, C. Bertoldo, M. Kähler, and G. Antranikian, "Extremophiles as a source of novel enzymes for industrial application," Applied Microbiology and Biotechnology, vol. 51, no. 6, pp. 711-729, 1999.

[34] J. Matzke, A. Herrmann, E. Schneider, and E. P. Bakker, "Gene cloning, nucleotide sequence and biochemical properties of a cytoplasmic cyclomaltodextrinase (neopullulanase) from Alicyclobacillus acidocaldarius, reclassification of a group of enzymes," FEMS Microbiology Letters, vol. 183, no. 1, pp. 5561, 2000.

[35] H. Leemhuis, What makes cyclodextrin glycosyltransferase a transglycosylase [Ph.D. thesis], University of Groningen, Groningen, The Netherlands, 2003.

[36] H. Aoki and Y. Sakano, "A classification of dextran-hydrolysing enzymes based on amino-acid-sequence similarities," Biochemical Journal, vol. 323, no. 3, pp. 859-861, 1997.

[37] F. Niehaus, A. Peters, T. Groudieva, and G. Antranikian, "Cloning, expression and biochemical characterisation of a unique thermostable pullulan-hydrolysing enzyme from the hyperthermophilic archaeon Thermococcus aggregans," FEMS Microbiology Letters, vol. 190, no. 2, pp. 223-229, 2000.

[38] B. E. Norman, "A novel debranching enzyme for application in the glucose syrup industry," Starch-Stärke, vol. 34, no. 10, pp. 340-346, 1982.

[39] A. Kubo, N. Fujita, K. Harada, T. Matsuda, H. Satoh, and Y. Nakamura, "The starch-debranching enzymes isoamylase and pullulanase are both involved in amylopectin biosynthesis in rice endosperm," Plant Physiology, vol. 121, no. 2, pp. 399-410, 1999.

[40] E. Lévêque, Š. Janeček, B. Haye, and A. Belarbi, “Thermophilic archaeal amylolytic enzymes," Enzyme and Microbial Technology, vol. 26, no. 1, pp. 3-14, 2000.

[41] K. Ara, K. Saeki, K. Igarashi et al., "Purification and characterization of an alkaline amylopullulanase with both $\alpha-1,4$ and $\alpha-1,6$ hydrolytic activity from alkalophilic Bacillus sp. KSM1378," Biochimica et Biophysica Acta, vol. 1243, no. 3, pp. 315324, 1995.

[42] T. Kuriki, S. Okada, and T. Imanaka, "New type of pullulanase from Bacillus stearothermophilus and molecular cloning and 
expression of the gene in Bacillus subtilis," Journal of Bacteriology, vol. 170, no. 4, pp. 1554-1559, 1988.

[43] A. Sunna, M. Moracci, M. Rossi, and G. Antranikian, "Glycosyl hydrolases from hyperthermophiles," Extremophiles, vol. 1, no. 1, pp. 2-13, 1997.

[44] H. Guzman-Maldonado and O. Paredes-Lopez, "Amylolytic enzymes and products derived from starch: a review," Critical Reviews in Food Science and Nutrition, vol. 35, no. 5, pp. 373403, 1995.

[45] R. E. Hebeda, T. Nagodawithana, and G. Reed, "Starches, sugars, and syrups," in Enzymes in Food Processing, pp. 321343, 3rd edition, 1993.

[46] M. Chaplin, "Production of glucose syrup," 2004, http://www .lsbu.ac.uk/biology/enztech/glucose.html.

[47] F. Shiraishi, K. Kawakami, and K. Kusunoki, "Kinetics of condensation of glucose into maltose and isomaltose in hydrolysis of starch by glucoamylase," Biotechnology and Bioengineering, vol. 27, no. 4, pp. 498-502, 1985.

[48] M. A. Hassan, Y. Shirai, A. Kubota, M. I. A. Karim, K. Nakanishi, and K. Hashimoto, "Effect of oligosaccharides on glucose consumption by Rhodobacter sphaeroides in polyhydroxyalkanoate production from enzymatically treated crude sago starch," Journal of Fermentation and Bioengineering, vol. 86, no. 1, pp. 57-61, 1998.

[49] W. D. Crabb and J. K. Shetty, "Commodity scale production of sugars from starches," Current Opinion in Microbiology, vol. 2, no. 3, pp. 252-256, 1999.

[50] M. Poliakoff and P. Licence, "Sustainable technology: green chemistry," Nature, vol. 450, no. 7171, pp. 810-812, 2007.

[51] Y. Suzuki, K. Hatagaki, and H. Oda, "A hyperthermostable pullulanase produced by an extreme thermophile, Bacillus flavocaldarius KP 1228, and evidence for the proline theory of increasing protein thermostability," Applied Microbiology and Biotechnology, vol. 34, no. 6, pp. 707-714, 1991.

[52] Y. Takasaki, A. Hayashida, Y. Ino, T. Ogawa, S. Hayashi, and K. Imada, "Cell-bound pullulanase from Streptomyces sp. No. 27," Bioscience, Biotechnology, and Biochemistry, vol. 57, no. 3, pp. 477-478, 1993.

[53] B. C. Saha, R. Lamed, C. Y. Lee, S. P. Mathupala, and J. G. Zeikus, "Characterization of an endo-acting amylopullulanase from Thermoanaerobacter strain B6A," Applied and Environmental Microbiology, vol. 56, no. 4, pp. 881-886, 1990.

[54] A. Spreinat and G. Antranikian, "Purification and properties of a thermostable pullulanase from Clostridium thermosulfurogens EM1 which hydrolyses both $\alpha-1,6$ and $\alpha$-1,4-glycosidic linkages," Applied Microbiology and Biotechnology, vol. 33, no. 5, pp. 511-518, 1990.

[55] S. H. Brown and R. M. Kelly, "Characterization of amylolytic enzymes, having both $\alpha-1,4$ and $\alpha-1,6$ hydrolytic activity, from the thermophilic archaea Pyrococcus furiosus and Thermococcus litoralis," Applied and Environmental Microbiology, vol. 59, no. 8, pp. 2614-2621, 1993.

[56] F. Canganella, C. M. Andrade, and G. Antranikian, "Charactevization of amylolytic and pullulytic enzymes from thermophilic archaea and from a new Fervidobacterium species," Applied Microbiology and Biotechnology, vol. 42, no. 2-3, pp. 239-245, 1994.

[57] K. A. Smith and A. A. Salyers, "Characterization of a neopullulanase and an $\alpha$-glucosidase from Bacteroides thetaiotaomicron 95-1," Journal of Bacteriology, vol. 173, no. 9, pp. 2962-2968, 1991.

[58] M. J. Yebra, J. Arroyo, P. Sanz, and J. A. Prieto, "Characterization of novel neopullulanase from Bacillus polymyxa," Applied
Biochemistry and Biotechnology, vol. 68, no. 1-2, pp. 113-120, 1997.

[59] K. Ara, K. Igarashi, K. Saeki, S. Kawai, and S. Ito, "Purification and some properties of an alkaline pullulanase from alkalophilic Bacillus sp. KSM-1876," Bioscience, Biotechnology, and Biochemistry, vol. 56, no. 1, pp. 62-65, 1992.

[60] C. Bertoldo, M. Armbrecht, F. Becker, T. Schäfer, G. Antranikian, and W. Liebl, "Cloning, sequencing, and characterization of a heat- and alkali-stable type I pullulanase from Anaerobranca gottschalkii," Applied and Environmental Microbiology, vol. 70, no. 6, pp. 3407-3416, 2004.

[61] J. T. Chen, M. C. Chen, L. L. Chen, and W. S. Chu, "Structure and expression of an amylopullulanase gene from Bacillus stearothermophilus TS-23," Biotechnology and Applied Biochemistry, vol. 33, no. 3, pp. 189-199, 2001.

[62] T. Kuriki, J. H. Park, S. Okada, and T. Imanaka, "Purification and characterization of thermostable pullulanase from Bacillus stearothermophilus and molecular cloning and expression of the gene in Bacillus subtilis," Applied and Environmental Microbiology, vol. 54, no. 11, pp. 2881-2883, 1988.

[63] S. Michaelis, C. Chapon, and C. D’Enfert, "Characterization and expression of the structural gene for pullulanase, a maltose-inducible secreted protein of Klebsiella pneumoniae," Journal of Bacteriology, vol. 164, no. 2, pp. 633-638, 1985.

[64] J. W. Kim, "Molecular cloning and characterization of a thennostable pullulanase from a Thermus Strain IM6501," Food Science and Biotechnology, vol. 9, no. 3, pp. 188-194, 2000.

[65] M. Erra-Pujada, F. Chang-Pi-Hin, P. Debeire, F. Duchiron, and M. J. O'donohue, "Purification and properties of the catalytic domain of the thermostable pullulanase type II from Thermococcus hydrothermalis," Biotechnology Letters, vol. 23, no. 16, pp. 1273-1277, 2001.

[66] M. Bibel, C. Brettl, U. Gosslar, G. Kriegshäuser, and W. Liebl, "Isolation and analysis of genes for amylolytic enzymes of the hyperthermophilic bacterium Thermotoga maritima," FEMS Microbiology Letters, vol. 158, no. 1, pp. 9-15, 1998.

[67] G. D. Albertson, R. H. McHale, M. D. Gibbs, and P. L. Bergquist, "Cloning and sequence of a type I pullulanase from an extremely thermophilic anaerobic bacterium, Caldicellulosiruptor saccharolyticus," Biochimica et Biophysica Acta, vol. 1354, no. 1, pp. 35-39, 1997.

[68] S. P. Lee, M. Morikawa, M. Takagi, and T. Imanaka, "Cloning of the aapT gene and characterization of its product, $\alpha$ amylase- pullulanase (AapT), from thermophilic and alkaliphilic Bacillus sp. strain XAL601," Applied and Environmental Microbiology, vol. 60, no. 10, pp. 3764-3773, 1994.

[69] R. Ohba and S. Ueda, "Purification, crystallization and some properties of intracellular pullulanase from Aerobacter aerogenes," Agricultural and Biological Chemistry, vol. 37, no. 12, pp. 2821-2826, 1973.

[70] H. Bender and K. Wallenfels, "Untersuchungen an Pullulan. II. Spezifischer Abbau durch ein bakterielles Enzym," Biochemische Zeitschrift, vol. 334, pp. 79-95, 1961.

[71] M. G. Kornacker and A. P. Pugsley, "Molecular characterization of pulA and its product, pullulanase, a secreted enzyme of Klebsiella pneumoniae UNF5023," Molecular Microbiology, vol. 4, no. 1, pp. 73-85, 1990.

[72] M. Klingeberg, H. Hippe, and G. Antranikian, "Production of the novel pullulanases at high concentrations by two newly isolated thermophilic clostridia," FEMS Microbiology Letters, vol. 69, no. 1-2, pp. 145-152, 1990. 
[73] S. H. Brown, H. R. Costantino, and R. M. Kelly, "Characterization of amylolytic enzyme activities associated with the hyperthermophilic archaebacterium Pyrococcus furiosus," Applied and Environmental Microbiology, vol. 56, no. 7, pp. 1985-1991, 1990.

[74] W. D. Crabb and C. Mitchinson, "Enzymes involved in the processing of starch to sugars," Trends in Biotechnology, vol. 15, no. 9, pp. 349-352, 1997.

[75] K. Horikoshi, "Alkaliphiles: some applications of their products for biotechnology," Microbiology and Molecular Biology Reviews, vol. 63, no. 4, pp. 735-750, 1999.

[76] Y. Hatada, K. Saito, H. Hagihara, K. Ozaki, and S. Ito, "Nucleotide and deduced amino acid sequences of an alkaline pullulanase from the alkaliphilic bacterium Bacillus sp. KSM1876," Biochimica et Biophysica Acta, vol. 1545, no. 1-2, pp. 367-371, 2001.

[77] T. Imanaka and T. Kuriki, "Pattern of action of Bacillus stearothermophilus neopullulanase on pullulan," Journal of Bacteriology, vol. 171, no. 1, pp. 369-374, 1989.

[78] F. J. M. Mergulhão, D. K. Summers, and G. A. Monteiro, "Recombinant protein secretion in Escherichia coli," Biotechnology Advances, vol. 23, no. 3, pp. 177-202, 2005.

[79] H. S. Olsen, P. Goddard, and A. S. Novo Nordisk, Enzymes at Work: A Concise Guide to Industrial Enzymes and their Uses, Novo Nordisk A/S, 2000.

[80] I. Gomes, J. Gomes, and W. Steiner, "Highly thermostable amylase and pullulanase of the extreme thermophilic eubacterium Rhodothermus marinus: production and partial characterization," Bioresource Technology, vol. 90, no. 2, pp. 207-214, 2003.

[81] J. F. Shaw and J. R. Sheu, "Production of high-maltose syrup and high-protein flour from rice by an enzymatic method," Bioscience, Biotechnology, and Biochemistry, vol. 56, no. 7, pp. 1071-1073, 1992.

[82] P. Nigam and D. Singh, "Enzyme and microbial systems involved in starch processing," Enzyme and Microbial Technology, vol. 17, no. 9, pp. 770-778, 1995.

[83] J. D. Dziezak, "Ingredients for sweet success," Food Technology, vol. 43, no. 10, pp. 94-116, 1989.

[84] W. Vorwerg, S. Radosta, and E. Leibnitz, "Study of a preparative-scale process for the production of amylose," Carbohydrate Polymers, vol. 47, no. 2, pp. 181-189, 2002.

[85] A. R. Bird, I. L. Brown, and D. L. Topping, "Starches, resistant starches, the gut microflora and human health," Current issues in Intestinal Microbiology, vol. 1, no. 1, pp. 25-37, 2000.

[86] S. Jobling, "Improving starch for food and industrial applications," Current Opinion in Plant Biology, vol. 7, no. 2, pp. 210-218, 2004.

[87] M. Schallmey, A. Singh, and O. P. Ward, "Developments in the use of Bacillus species for industrial production," Canadian Journal of Microbiology, vol. 50, no. 1, pp. 1-17, 2004.

[88] J. A. Rendleman Jr., "Enhancement of cyclodextrin production through use of debranching enzymes," Biotechnology and Applied Biochemistry, vol. 26, no. 1, pp. 51-61, 1997.

[89] Y. K. Kim and J. F. Robyt, "Enzyme modification of starch granules: formation and retention of cyclomaltodextrins inside starch granules by reaction of cyclomaltodextrin glucanosyltransferase with solid granules," Carbohydrate Research, vol. 328, no. 4, pp. 509-515, 2000.

[90] M. Marotta, A. Martino, A. De Rosa, E. Farina, M. Cartenì, and M. De Rosa, "Degradation of dental plaque glucans and prevention of glucan formation using commercial enzymes," Process Biochemistry, vol. 38, no. 1, pp. 101-108, 2002. 

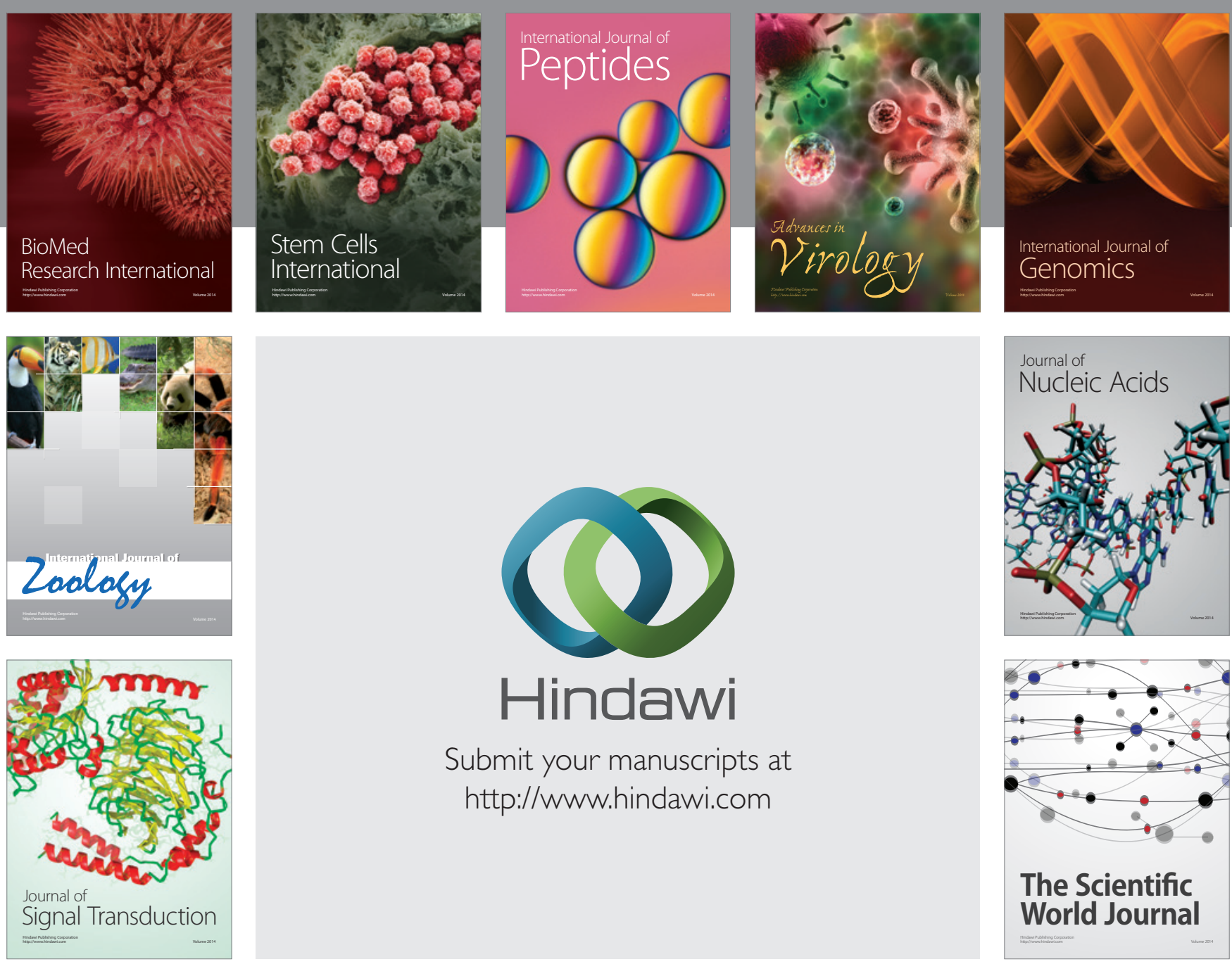

Submit your manuscripts at

http://www.hindawi.com
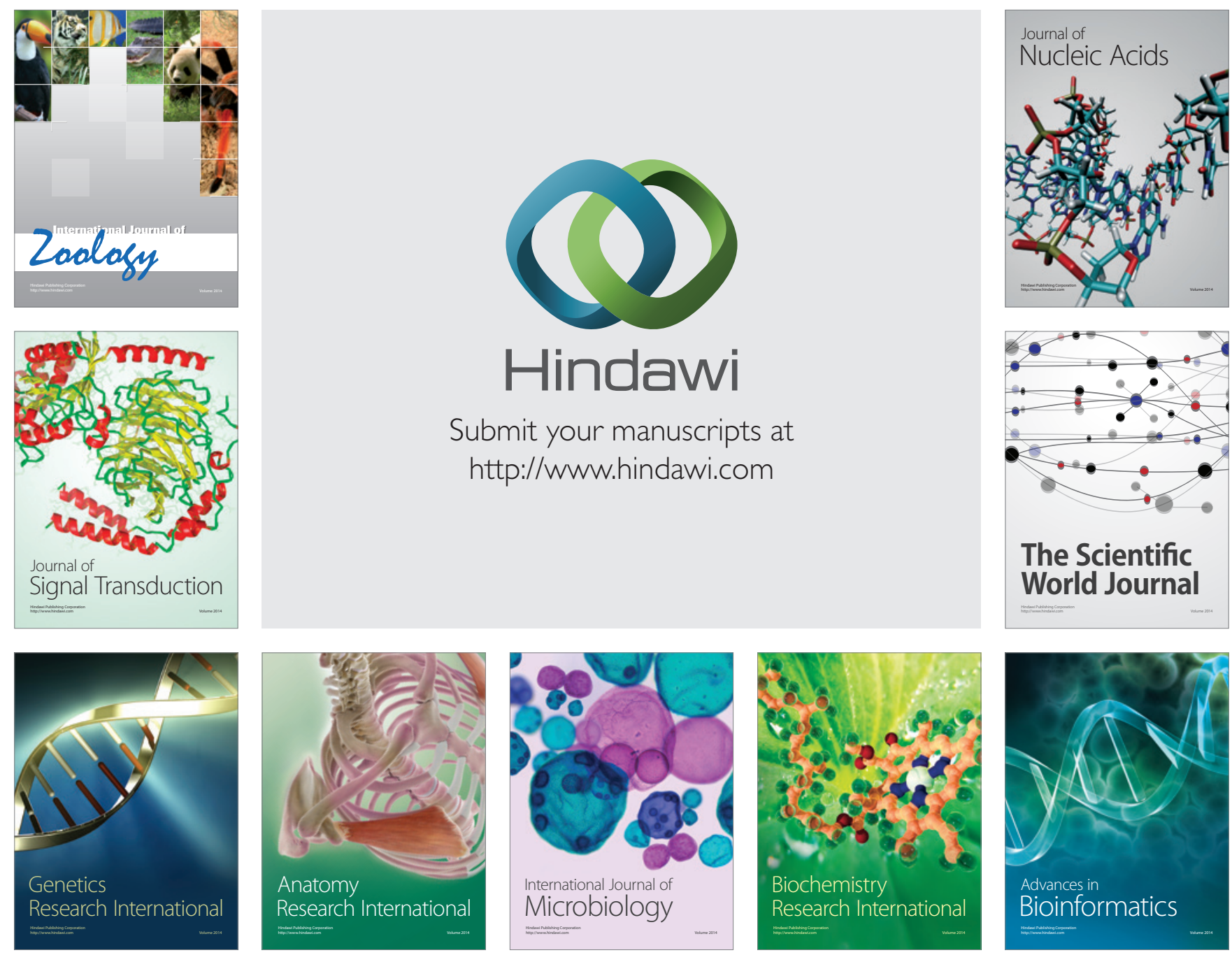

The Scientific World Journal
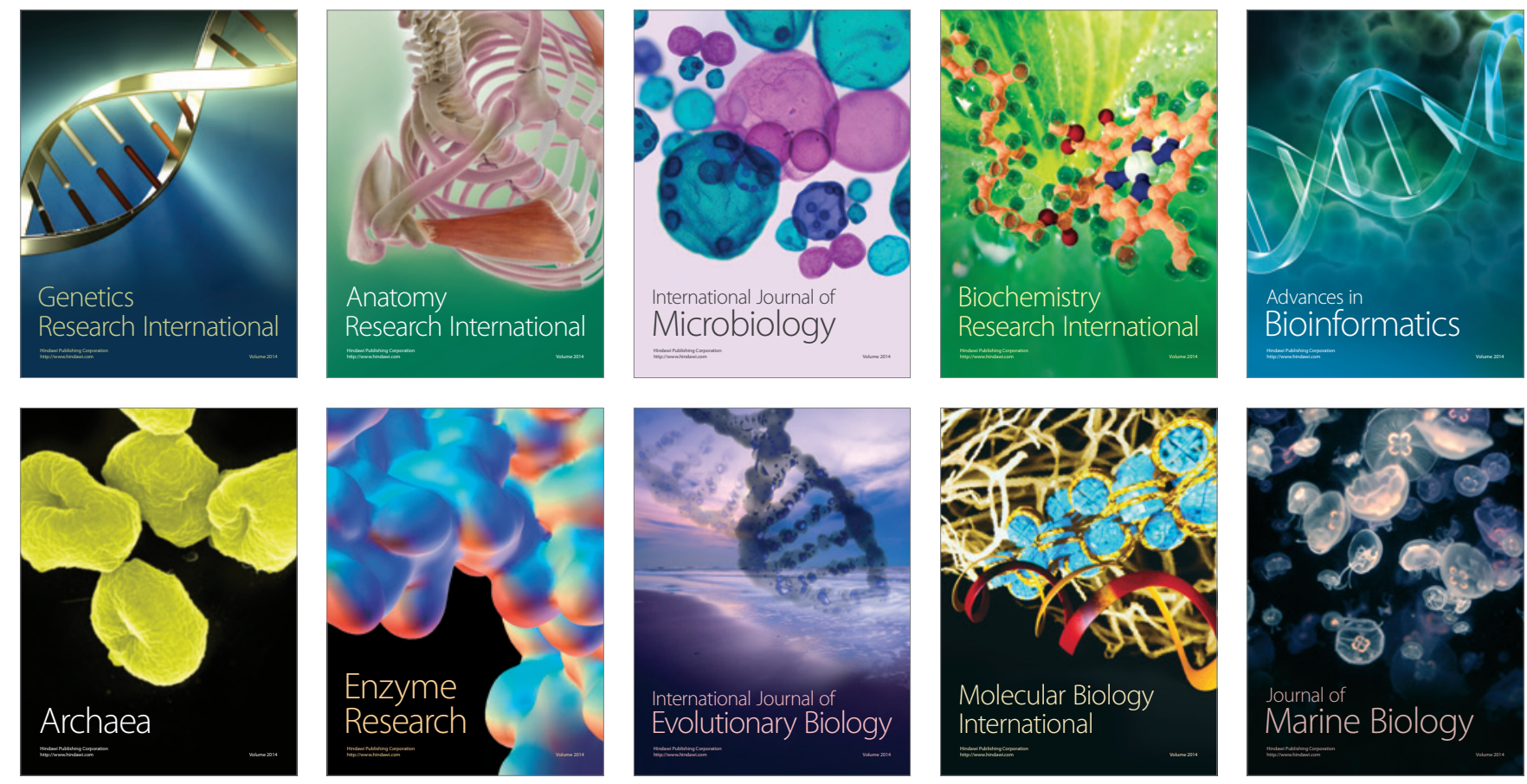